\title{
К ВОПРОСУ О ПРАВОПОНИМАНИИ. ФИЛОСОФСКО-ПРАВОВОЙ ВЗГЛЯД НА КЛАССИЧЕСКИЙ И ПОСТКЛАССИЧЕСКИЙ ТИПЫ ПРАВОПОНИМАНИЯ РОССИИ 19-20 ВЕКА
}

\author{
(C) 2021 Сухобок Татьяна Владимировна
}

аспирант кафедры «Теории и истории права и государства; Истории учений о праве и государстве» Балтийский федеральный университет имени Иммануила Канта, Россия, Калининград

E-mail: sukhobok94@mail.ru

В статье показано теоретическое и практическое значение правопонимания. Рассматривается представление отечественных философов о концепции естественного права. Рассмотрена отечественная правовая мысль представителей школы возрожденного естественного права. Даётся понятие и выделяются основные особенности постклассического типа правопонимания. Показано влияние политики государства на процесс развития и становления идей естественного права. Выявлены особенности отечественной правовой мысли и правопонимания.

Ключевые слова: Естественное право, возрожденное естественное право, постклассический тип правопонимания, право, правопонимание, государство.

Право является уникальным, сложным и общественно необходимым феноменом. На протяжении всего времени существования и развития права научный интерес к данному феномену не исчезает. Вопросы правопонимания принадлежат к числу «вечных» уже потому, что человек на каждом из витков своего индивидуального и общественного развития открывает в праве новые качества и новые аспекты соотношения его с другими явлениями и сферами жизнедеятельности социума.

Правопонимание - это научная категория, отражающая процесс и результат целенаправленной мыслительной деятельности человека, включающий в себя познание права, его восприятие (оценку) и отношение к нему как к целостному социальному явлению. Постоянно происходящие изменения в обществе, вынуждают к трансформации правопонимания. В результате складывается новая картина правовой реальности и новая правовая теория.

Правовая теория в качестве основы построения использует определенное понимание права, которое выступает как основа познания правовых феноменов. Поэтому понятие права содержит в себе определенную правовую концепцию. Но, важнее то, что образ права, складывающийся в рамках определенного типа правопонимания оказывает влияние на реализацию права на законодательном уровне.

Приступая к изучению классического и постклассического типов правопонимания, не- обходимо понять какое место занимает категория «правопонимание» в системе юридического научного знания. Тип право понимания - это теоретико-методологический подход к формированию определения права. Многообразие представлений о праве связано с социокультурными и индивидуальными характеристиками [1, C. 40].

Так, в каждом временном периоде формируется свое направление правопонимания.

В конце 19 - начале 20 в. концепция естественного права относилась к классической правовой доктрине и включала положения о том, что наряду с изменчивым положительным правом существует вечное естественное право [2, С. 257-258].

Концепция естественного права развивалась и неоднократно изменялась до начала 20 в. Основные положения концепции естественного права нашли отражение в теоретических работах отечественных правоведов и философов: В.Н. Татищева, А.П. Куницина, А.Н. Радищева и д.p.

На период первой половины 19 в. приходится новый этап развития в отечественной юриспруденции концепции естественного права. Однако, в вопросах интерпретации позитивного права российская юриспруденция оставалась догматической [3].

Необходимо так же учитывать, что на становление российской теории естественного права оказали влияние работы европейских ученых: 
Г. Гроция, К. Томазиуса, К. Вольфа, Р.Потье и д.р.

Не смотря на активное развитие правовой мысли российских правоведов и философов политика государства не давала идеям естественного права развития на законодательном уровне. 26 июля 1835 г. был утвержден общий устав Императорских Российских Университетов [4], который содержал положения о запрете преподавания естественного права. Это привело к тому, что на практике государство ограничивало законодательно развитие естественного права. Только в 19 в. в отечественные институты вернулось преподавание идей естественного права.

Следующий этап развития отечественного права связан с судебной реформой Александра II утвержденной указом от 20 ноября 1864 г. [5]. Данной реформой была создана судебная система, которая на тот период была самой передовой в мире [6, С. 15].

Развитие отечественной правовой мысли привело к тому, что в середине 19 в. идеи русских правоведов и философов стали частью кодифицированного законодательства, а идеи естественного права вошли в российскую догматическую юриспруденцию.

В период 19-20 в. на отечественную концепцию естественного права оказала огромное влияние немецкая философия. Немецкий юрист и философ Р.Штаммлер положил начало пониманию естественного права с изменяющимся содержанием, что получило дальнейшее развитие в российской философии права. [7, С. 304].

Большое значение в развитие русской правовой мысли внес отечественный философ права и общественный деятель П.И.Новгородцев. Идею естественного права по утверждению П.И.Новгородцева следует рассматривать в рамках вечного неотъемлемого права человеческой личности [8, С. 30]. «Естественное право - это и протест личности против властного произвола, и требование лучшего законодательства, и моральная основа для общественного строя, и государства, гарантирующего права и свободы человека.». Так, в конце 19 - начале 20 в. естественное право в русской правовой мысли стало восприниматься как регулятор общественных отношений.

Следует сказать о возрождённом естественном праве. Идеи необходимости этого возрождения впервые были озвучены в конце 19 в. в трудах отечественных правоведов и философов: П.И.Новгородцева и Л.И.Петражицкого, Е.Н. Трубецкого, Б. А. Кистяковского и др.
Идеи школы возрожденного естественного права по мнению П.И.Новгородцева строились на том, что «в отличие от классического естественного права, в котором нормы имели незыблемый характер, новое не содержит системы неизменных норм, но познает безусловное начало, позволяющее достичь тех рубежей, которые задаются праву обстоятельствами конкретного времени и пространства» [9, С. 269].

Переход к постклассическому типу правопонимания в философии права связан с отказом от разделения на субъект и объект процесса познания. Постклассическому правопониманию присуща включенность субъекта в право и акт его познания. Здесь право не рассматривается как внешний субъекту объект, а вопрос о его сущности, заменяется вопросом о его смысле в контексте социокультурных детерминант, обусловливающих его изменение и функционирование в обществе. В отличие от классического, постклассическое правопонимание культивирует идею незавершенности, процессуальности права, что выражается в апелляции к его социокультурным детерминантам, имеющим содержательные и формальные свойства [10, С. 91].

Таким образом, вопрос о типах правопонимания на протяжении всего развития отечественной правовой мысли привлекает исследователей, т.к. относится к числу фундаментальных, и в зависимости от ответа на него могут быть разные представления об источниках права, о толковании права, и о правоприменении. Так же, представляется важным вопрос формирования отечественной правовой мысли [11, C. 9].

Правопонимание - результат как рационального, теоретического осмысления права в его онтологической сущности, так и следствие его иррационального восприятия, так как понимание права всегда происходит в социокультурном контексте жизненного мира субъектов. В свою очередь, тип правопонимания - это формирующийся в рамках определенной культуры образ права, который характеризуется как парадигмально обусловленными теоретическими признаками права, так и культурно обусловленным практическим отношением к праву.

Каждый тип правопонимания имеет положительные и отрицательные стороны, которые могут проявляться в большей или меньшей степени в зависимости от политико-правового мышления и уровня правосознания общества. 
Несмотря на близость отечественных правоведов и философов права 19-20 вв. к идеям естественного права заключенным в работах ряда европейских ученых, и оказания огромного влияния немецкой философии на отечественную концепцию естественного права, отечественную правовую мысль можно назвать уникальной. Отечественная правая мысль была сформиро- вана из соединения различных идей о праве с учетом социально-политических тенденций. Отечественное правопонимание складывалось с учетом особенностей политики государства 1920 вв, идей и положений о естественном праве отечественных правоведов и философов, и использованием опыта зарубежной юридической науки.

\section{Библиографический список}

1. Финогентова О.Е., Долголенко Т.Н. Интегративные концепции как основа современного отечественного правопонимания / Финогентова О.Е., Долголенко Т.Н. // Вестник СЮИ, 2011.

2. Любашии В.Я., Смоленский М.Б., Шепелев В.И. Теория государства и права. / Любашиц В.Я., Смоленский М. Б., Шепелев В. И. - Ростов-на-Дону: Феникс, 2003.

3. Борисова Т. Ю. Сборник законов Российской Империи: феномен самодержавной законности / Т.Ю Борисова // Право и история. 2012. Обзор № 30 (03).

4. Высочайше утвержденный Общий устав Императорских Российских Университетов от 26 июля 1835 г. электронный ресурс: https://base.garant.ru/58090287.

5. Судебные уставы 20 ноября 1864 г., с изложением рассуждений, на коих они основаны. Часть первая. электронный ресурс: https://civil.consultant.ru/reprint/books/115/3.html.

6. Томсинов В. А. Юридическое образование и юриспруденция в Россиив эпоху «великих реформ» (60-е - начало 80-х гг. XIX в.): Учебное пособие / В.А. Томсинов; Московский гос. ун-т им. М. В. Ломоносова, Юридический фак., Каф. истории государства и права. Москва: Зерцало. - М, 2013.

7. Жариков А.А. Понимание возрожденного естественного права на рубеже XIX-XX веков в России / Жариков А. А. // МНИЖ. 2019. № 9-2.

8. Сухобок Т.В. Классический тип правопонимания. Естественное право в русской правовой мысли XIXХХ века/ Сухобок Т. В. // Вопросы экономики и права. 2021. № 158.

9. Новгородцев П.И. Ведение в философию права: Кризис соврем. правосознания / П.И.Новгородцев; МВД России. С.-Петерб. ун-т. Акад. права, экономики и безопасности жизнедеятельности. СПб.: Лань и др. 2000.

10. Сизова Н. М. Классическое и постклассическое правопонимание: онтологические, гносеологические, аксиологические и эпистемологические критерии соотношения/ Сизова Н. М. // Философия права. 2014. № 1.

11. Кожевников В.В. Проблемы типов правопонимания в отечественной юриспруденции / Кожевников В.В.// Вестник ОмГУ. Серия. Право. 2017. № 4 (53). 